\title{
Leakproofness of the reinforced concrete tank for water with a capacity of $45000 \mathrm{~m}^{3}$
}

\author{
Maciej Y. Minch ${ }^{1}$, and Andrzej Kmita ${ }^{1, *}$ \\ ${ }^{1} \mathrm{TU}$ of Wroclaw, Civil Engineering department, Wroclaw, Poland
}

\begin{abstract}
The clean water tank discussed consists of four reinforced concrete tanks. The structure is symmetrical for each of the tank pairs, which consist of two storage tanks and two water transfer tanks for the water supply network. All chambers are technologically connected with each other. The tanks are partially recessed in the ground, monolithic, and completely roofed. The projection of chambers within external walls is $96 \times 96 \mathrm{~m}=9,216 \mathrm{~m}^{2}$. The total capacity of internal chambers and external chambers is about $45,000 \mathrm{~m}^{3}$. The clean water tank was made as a reinforced concrete structure, monolithic. The owner of the facility observed significant losses of stored water, which translated into large financial losses of the company. In order to determine the current technical condition of the reservoir and the causes of its leakage, a comprehensive, multi-level analysis was carried out in terms of strength, stability and durability of the structure. A few dozens of samples were taken at random, and the compressive strength of the concrete, modulus of longitudinal deformation and degree of carbonatization were evaluated. For the assessment of the technical condition of the expansion joints, boreholes were also drilled through them. On the basis of the results obtained from the tests, numerical analysis of the stress on the structure and its deformations was performed in order to select the most stressed areas as well as to assess expansion deformations as potential spots of the largest leaks. The results of the analysis were used to prepare the concept of sealing repairs of the tank chambers.
\end{abstract}

\section{Description of the facility}

The facility in question consists of four tanks. In terms of construction, each tank is a separate, unconnected unit, independent of the neighbouring tank. The tanks are technologically connected and located parallel to the longitudinal walls. The tanks are partially recessed in the ground, monolithic, and completely roofed, with prefabricated structure based on prestressed concrete girders.

The archival design documentation of the structure, which the drawings were taken from, was prepared in 1978. The tanks were put into service in 1980. The total capacity of the two internal chambers (No. 2 and 3) with dimensions in the projection of $12 \times 96 \mathrm{~m}$ and two external chambers (No. 1 and 4), $36 \times 96 \mathrm{~m}$, is about 45,000 $\mathrm{m}^{3}$. The surface of the tank within the external walls is $96 \times 96 \mathrm{~m}=9216 \mathrm{~m}^{2}$.

\footnotetext{
${ }^{*}$ Corresponding author: andrzej.kmita@pwr.edu.pl
} 
The archival projection of the half-tank to the symmetry axis is shown in Fig. 1, and the archival section through the external wall of the tank is shown in Fig. 2.

The clean water tank was made as a reinforced concrete structure, monolithic. It is used for storing water in order to smooth out changing needs over time. From the clean water tank, the water is pumped out and taken into the municipal water supply network through main pipelines.

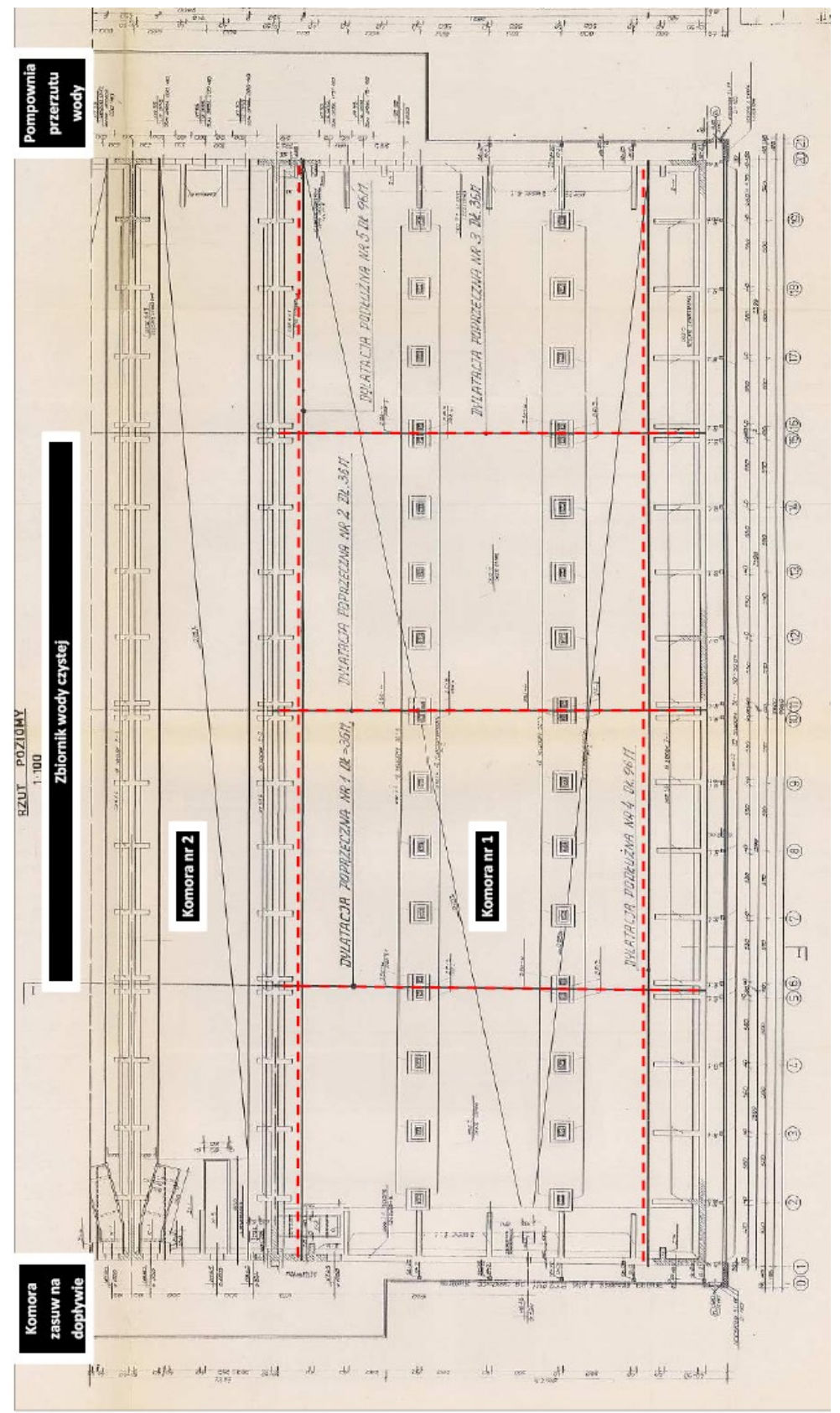

Fig. 1. Archival projection of the tank to the symmetry axis on the upper edge of the smaller tank No.2. 


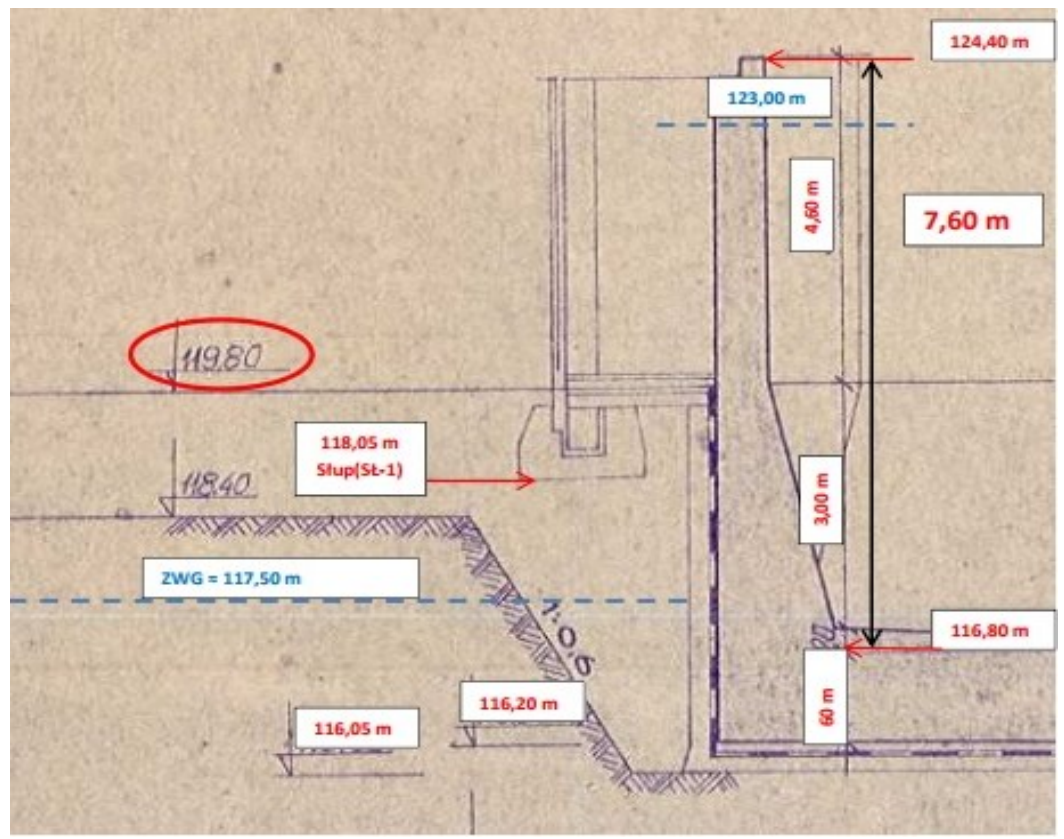

Fig. 2. Archival section through the external wall of the tank (in the figure, corrections of dimensions and levels in relation to archival data made during on-the-spot checks).

Facilities used for water supply and drainage were made at the gable walls of the reservoirs. The facilities consist of an underground and above-ground part; they directly adjoin the tanks and are connected by technological piping with water tanks.

The concrete construction of tanks is based on the metallurgical cement "350" with the strength of $\mathrm{Rw}=200 \mathrm{~kg} / \mathrm{cm}^{2}(\sim 20 \mathrm{MPa})$ with the addition of hydrobet sealant in the amount of $1.5 \%$ by weight to cement; water permeability was determined for W-4 (strength is presented in the original units included in the design).

Reinforcing steel $18 \mathrm{G} 2$ with $\mathrm{Qr}=3600 \mathrm{~kg} / \mathrm{cm}^{2}(\sim 360 \mathrm{MPa})$ and auxiliary smooth steel $\mathrm{St} 0$ with $\mathrm{Qr}=2500 \mathrm{~kg} / \mathrm{cm}^{2}(\sim 250 \mathrm{MPa})$.

The bottom of the tank was designed as a bi-directionally reinforced slab in the form of an inverted mushroom ceiling with discharged column heads in the form of foundation goblets. The slab was placed on the native ground of the sand layer on lean concrete with $\mathrm{Rw}=90 \mathrm{~kg} / \mathrm{cm}^{2}(\sim 9,00 \mathrm{MPa})$. The insulation is made up of three layers of tar paper on an asphalt binder with the middle layer of jute paper. The roof insulation was pressed with a layer of protective concrete, $0,05 \mathrm{~m}$ thick and with $\mathrm{Rw}=110 \mathrm{~kg} / \mathrm{cm}^{2}(\sim 11 \mathrm{MPa})$.

The vertical walls of the tank's shell were made as cantilever, fixed rigidly in the bottom slab. The walls are reinforced on both sides in the spots loaded with the ground or water. Horizontally, the walls are reinforced with distribution bars. Vertical corners are additionally reinforced against bending moments. In the near-bottom area, the tank walls have structural bevels.

The external walls of the tank chambers are $0.50 \mathrm{~m}$ thick at the bottom, and become gradually thinned to $0.40 \mathrm{~m}$ below the ceiling. While connecting the bottom with the walls of the chambers, $0.50 \times 0.50 \mathrm{~m}$ bevels were made. Longitudinal and gable walls are reinforced with ribs.

The bottom of the tank chambers is made with a drop of $0.25 \%$ in the opposite direction to the water flow towards the location of the collecting wells with the dimensions $1,00 \times 1,00 \times 0,60 \mathrm{~m}$ (four in total, one in each chamber). 
Discharge of water from the tank chambers to the above-ground chambers in the water transfer station takes place through bottom boreholes made in the construction of the tank gable wall and the walls of the draft chambers.

Due to the considerable length of the tanks, they are divided into four segments by three crosswise expansion joints, running through the bottom and walls of the tank. In addition, work breaks are provided for concreting the bottom and between the bottom and the walls. In the tanks with a width of $36.00 \mathrm{~m}$, work breaks are provided in the foundation slab and walls in the form of gaps with a width of $0.70 \mathrm{~m}$, designed to compensate for contractions. According to archival descriptions, these breaks were to be concreted up after a few months.

According to the technical description, expansion joints were placed in the work breaks and dilatation areas (see Fig. 3).

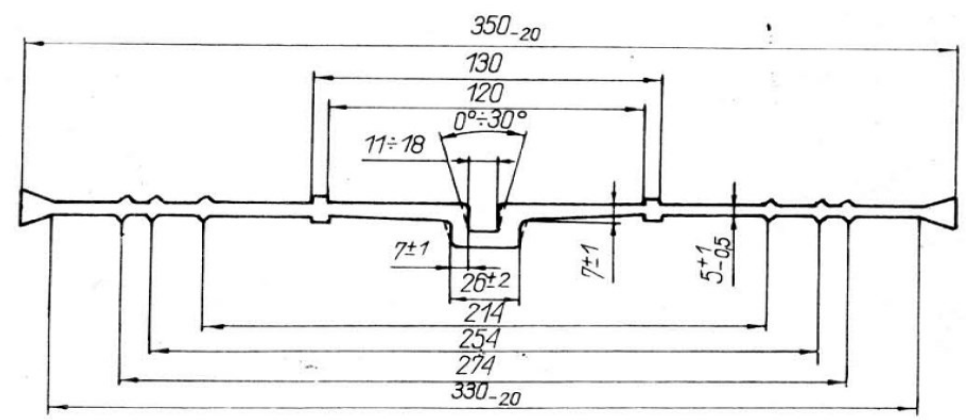

Fig. 3. Section through the expansion tape (dimension in mm, according to the design).

External insulation was traditional bituminous insulation. Three layers of tar paper were used for the bottom (description above); $0,12 \mathrm{~m}$ thick concrete wall was applied to press the insulation.

The internal insulation is made of fired cement setting coat, type II, with a content of $525 \mathrm{~kg}$ of cement per $1 \mathrm{~m}^{3}$ of mortar trowelled smooth. The waterproofing coating was recommended to be made in three layers. Layer I is the rendering coat made of thick slurry, $10-20 \mathrm{~mm}$ in thickness. Layer II, 8-10 mm thick, is made after partial hardening of the rendering coat, of the 1:2 mortar, with the use of steel smoothing trowels, with gradual compaction of the mortar until an even surface is obtained. After partial hardening, this layer had to be scratched. Layer III, the last one, with a thickness of 8-10 mm, was laid like layer II and trowelled smooth. Layer III was surface-sealed by firing after 24 hours.

\section{Testing the concrete tank structure}

The authors of the article have completed a thorough examination and assessment of the tanks' technical condition, providing repair solutions for them.

Referring to the standard provisions, it can be said that in the end the entire test procedure must answer the question whether the ultimate limit state (ULS) of the object has been exceeded, and also whether the requirements of the serviceability limit state (SLS) are met. In facilities such as tanks, special attention is paid to the serviceability limit state, which often determines the required reinforcement section related to the provision of resistance to cracking as well as tightness [1-3]. On the basis of the tests performed and the inventory, damage, usually in the form of concrete and $\left(\frac{\Delta A_{C}}{A_{C}}\right)$ and steel $\left(\frac{\Delta A_{S}}{A_{S}}\right)$ losses to the initial (design) state is assessed, and also the impact of the damage on the change (decrease) of the bearing capacity of the structural elements is determined. As a criterion, one can assume the 
degree of material strength utilization: concrete $\left(\frac{\sigma_{C}}{f_{C}}\right)$ and reinforcing steel $\left(\frac{\sigma_{S}}{f_{y}}\right)$ (where: $\sigma_{c}$ means stresses in concrete, and $\sigma_{s}$ means stresses in reinforcing steel for the analysed loads).

The service limit condition SLS can be expressed in the following form:

$$
\mathrm{E}_{d, \mathrm{ser}}\left(\mathrm{F}_{, k}\right) \leq \mathrm{C}_{d}
$$

where:

$E_{d, s e r}\left(F_{, k}\right)$ - value of the interactions effect (for characteristic loads),

$C_{d}$ - limit calculation value of the relevant serviceability parameter (deflection, deformation, gap width, allowable stress, local damage affecting the appearance and durability of the structure).

The above-mentioned criteria for meeting the ULS and SLS conditions require, first of all, the basic strength parameters of the materials, the geometry of the object, the proper static scheme with particular emphasis on the value and nature of the (static and dynamic) impact of the object's operation history and the adoption of the structure model (in relation to numerical calculations), which will again reflect the real work of the structure as accurately as possible.

All the above-mentioned parameters and their values require or even enforce a specific methodology of research.

The tank structure tests were carried out in the following scope:

- testing compressive concrete strength on core boreholes [4],

- testing of longitudinal deformation of concrete on core boreholes,

- assessment of the degree of concrete carbonatization

- assessment of the degree of reinforcement corrosion,

- determination of water permeability of concrete on core boreholes,

- assessment of reinforcement cover thickness and reinforcement distribution,

- morphology of cracks.

Based on the analysis of the obtained test results, it was found that the compressive strength of concrete meets the design requirements ; as a matter of fact it was often higher by two classes than required, while the coefficient of variation $\mathrm{C}=\sigma / \mathrm{x}$ and exceeds $25 \%$ ( $\sigma$-standard deviation, $x$-value of the average concrete strength), which means poor concrete quality [5]. For example, for external walls $\mathrm{f}_{\mathrm{c}, \min }=31.67 \mathrm{MPa}, \mathrm{f}_{\mathrm{c}, \max }=54.73 \mathrm{MPa}$. In total, 68 core boreholes were made to assess the strength parameters of the concrete.

The thickness of the carbonated concrete layer is, for external walls: average value of carbonated casing $\mathrm{c}_{\mathrm{m}}=21.5 \mathrm{~mm}, \mathrm{c}_{\max }=45 \mathrm{~mm}$, and for internal walls the average value of carbonated casing $\mathrm{c}_{\mathrm{m}}=10.0 \mathrm{~mm}, \mathrm{c}_{\max }=22 \mathrm{~mm}$. The degree of carbonatizaton inside the tank is about $50 \%$ smaller than on the outside.

Water permeability of concrete is, for all structural elements, above W10. The corrosion rate of steel in areas where the casing has been carbonated or is missing is from 20 to $70 \%$ (in relation to the initial section). Reinforcement cover thickness varies from 0 to $100 \mathrm{~mm}$.

Morphology of cracks; mainly vertical crackings with an aperture of $0.1 \mathrm{~mm}$ to $0.8 \mathrm{~mm}$ have been recorded (mainly cracks vary between $0.2 \mathrm{~mm}$ and $0.4 \mathrm{~mm}$ in thickness). Part of the observed cracks passes through concrete (leakages were detected while the chambers were being with water). Based on archival information, it was found that the basic causes of the leaks observed in the tanks were associated with insufficient reinforcement of walls for concrete shrinkage as well as faulty design of the bottom slab expansion joints.

All information collected from the research and macroscopic evaluation constituted a database for the assessment of the current technical condition of the facility and analysis of the actual stress upon the tank construction. 
In Fig. 4, a model view of damage inventory of the tank wall with crackings and corrosion of the reinforcement can be seen.

Tank No 2 - Wall (from tank No 1)

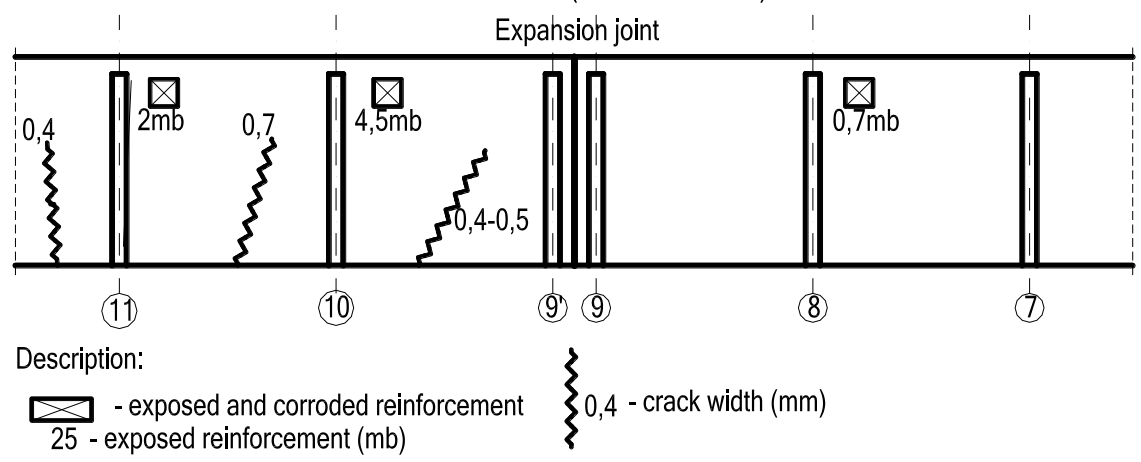

Fig. 4. Model view of a tank wall with damage of the structure.

\section{Computational analysis}

Computational analysis was aimed at determining the stress of the structure and its deformation due to affirmed damage, corrosion, scratches of the tank shell and excessive expansion of the expansion joints.

As a result of the measurements, a very different value was found of reinforcement cover from 0 (no cover) to a very large buffer zone of up to $100 \mathrm{~mm}$. Such discrepancies from inaccuracies and technically poor contracting, as well as from poor stiffening of the formwork, which was why the wall was made with even several dozen centimetres of geometric imperfections.

In the most damaged areas, where reinforcement corrosion is the greatest, the bars have a diameter of $30-40 \%$ smaller than the initial one, which translates into a smaller reinforcement area by $50-70 \%$, respectively. The structure is reinforced with ribbed bars of $34 \mathrm{GS}$ and $18 \mathrm{G} 2$ grades (the majority of rods is of the $18 \mathrm{G} 2$ grade). The concrete used for calculations was based on strength tests from core drilling C30/37.

The fragments of the tank cut off by dilations were used for calculations. The ground surface is made of small, medium and thick sands with good geotechnical parameters.

The fig. 5 below shows the spatial schematics of the structure of the tank half (the long side of the smaller tank is the axis of symmetry for the entire geometrical structure of the result construction).

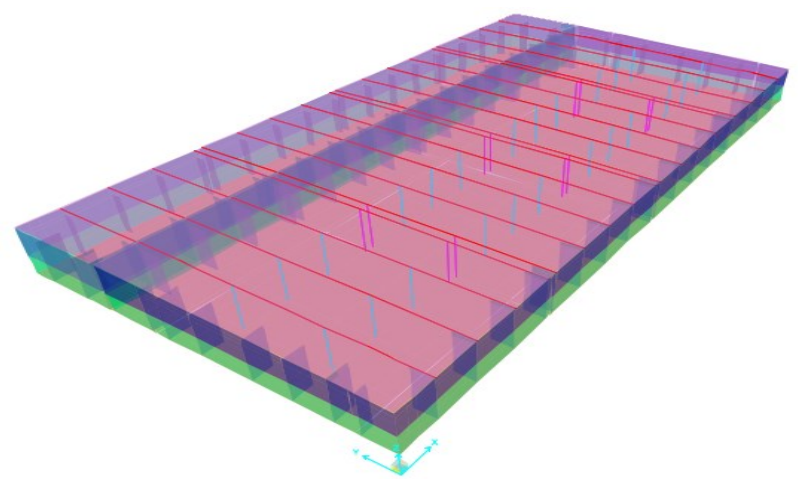

Fig. 5. Spatial modelling scheme of clean water tank. 


\subsection{Checking the unsealing of the expansion joints}

The following SGU combination was adopted to check the unsealing of the expansion joints in the transverse wall: $1,0 \cdot$ constant $+0,8 \cdot$ water $+0,8 \cdot$ ground

Fig. 6 shows the displacements of the tank's extreme section due to the water load.

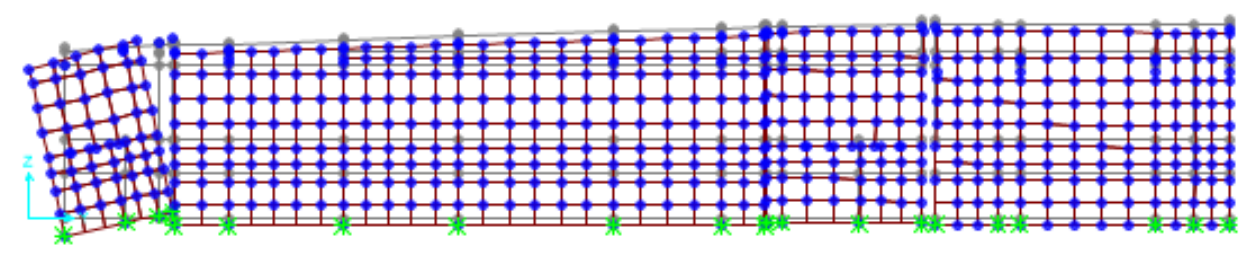

Fig. 6. Displacements of the tank's extreme section due to water load.

The characteristic horizontal displacements of the top expansion joints resulting from individual loads were:

- Constant loads: $0.0752 \mathrm{~m}$

- Water pressure: $0.1527 \mathrm{~m}$

- Ground pressure: $-0.0156 \mathrm{~m}$

In further considerations, horizontal displacements from solid loads were omitted due to the sealing of the tank during contracting.

The total unsealing of the top expansion joints was:

$$
0,8 \cdot 0,1527 m-0,8 \cdot 0,0156 m=0,11 m
$$

Due to the fact that there was no such large unsealing of the expansion joints, the model was calibrated.

- Integrating of separated bottom parts

Due to the existing additional layers of the bottom, separated parts of the bottom were connected with a layer of concrete $0.05 \mathrm{~m}$ thick.

- Chafing the floor slab and girders against the wall

Additional horizontal forces at the top of the longitudinal wall resulting from the friction of individual elements were taken into account:

Floor slab weight according to KB1-31.5-1./8/-69 measuring 596x150x24 per $\mathrm{m}^{2}=$ $=2560 \mathrm{~kg} /\left(5.96 * 1,50 \mathrm{~m}^{2}\right)=286.35 \mathrm{~kg} / \mathrm{m}^{2}=>2.8635 \mathrm{kN} / \mathrm{m}^{2}$

The span from the axis of the outer wall to the axis of the column $=11.85 \mathrm{~m}$

Average vertical force operating from the floor slab to the external wall: $\left(2.8635 \mathrm{kN} / \mathrm{m}^{2 *} 11.85 \mathrm{~m}\right) / 2=16.97 \mathrm{kN}$

The friction factor adopted $=0,4$

Horizontal force operating from floor slabs $=16.97 * 0.4=6.79 \mathrm{kN} / \mathrm{m}$

Weight of the roof girder $=4000 \mathrm{~kg}=>40 \mathrm{kN}$

Average vertical force operating from the roof girder to the external wall: $40 \mathrm{kN} / 2=20 \mathrm{kN}$

Horizontal force operating from girders $=20 * 0.4=8 \mathrm{kN}$

- Cooperation of external poles

At the top of the longitudinal wall, in the axes of columns supporting the façade, elastic supports were added which took into account the cooperation of these columns.

Horizontal stiffness of columns: $3 \mathrm{EI} / \mathrm{L}^{3}=3 * 30 \mathrm{GPa} *(0.3 \mathrm{~m})^{4} / 12 /(6.55 \mathrm{~m})^{3}=216 \mathrm{kN} / \mathrm{m}$.

The following SGU combination was adopted to check the unsealing of the expansion joints in the transverse wall:

$$
1,0 \cdot \text { friction }+0,8 \cdot \text { water }+0,8 \cdot \text { ground } \cdot 2
$$

(In further calculations, if the tank was filled with water, the value of ground pressure impact was multiplied by 2). 
The characteristic horizontal displacements of the top expansion joints resulting from individual loads are:

- Friction: $-0.0054 \mathrm{~m}$

- Water pressure: $0.0375 \mathrm{~m}$

- Ground pressure: $-0.0064 \mathrm{~m}$

The total unsealing of the top expansion joints is:

$$
-1,0 \cdot 0,0054 m+0,8 \cdot 0,0375 m-0,8 \cdot 0,0064 m=0,01948 m
$$

This is a real value if one considers that the tank has never been filled to the designed operating condition.

\subsection{Checking the capacity of the tank}

The calculations were carried out in accordance with PN-EN 1992-3: 2008 and related standards.

$\mathrm{C} 30 / 37$ class concrete and steel grade $18 \mathrm{G} 2, \mathrm{fyk}=355 \mathrm{MPa}$, were used to calculate the individual sections

The analysis includes two extreme cases of reinforcement distribution (axial forces were not taken into account and compression reinforcement was omitted)):
a) $100 \mathrm{~mm}$ thick jacket, non-corroded reinforcement - Table 1,
b) $0 \mathrm{~mm}$ thick jacket, corroded reinforcement, the reinforcement area lesser by $70 \%$-Table 2,
c) State after repair : 40mm thick jacket, non-corroded reinforcement - Table 3.

Table 1. Distribution of reinforcement according to sub-point a).

\begin{tabular}{|c|c|c|c|c|c|c|c|c|}
\hline \multicolumn{9}{|l|}{ Case a) } \\
\hline orientation & diameter & span & $\mathbf{h}$ & d & As & xeff & $\xi$ eff & MRd \\
\hline$[-]$ & [m] & {$[\mathbf{m}]$} & {$[\mathbf{m}]$} & [m] & [m2] & [m] & {$[-]$} & [kNm] \\
\hline \multirow{3}{*}{ horizontal } & \multirow{3}{*}{0.014} & \multirow{3}{*}{0.1} & 0.5 & 0.393 & 0.001539 & 0.022176 & 0.056427 & 181 \\
\hline & & & 0.4 & 0.293 & 0.001539 & 0.022176 & 0.075686 & 134 \\
\hline & & & 0.3 & 0.193 & 0.001539 & 0.022176 & 0.114902 & 86 \\
\hline \multirow{8}{*}{ vertical } & \multirow{6}{*}{0.014} & \multirow{3}{*}{0.1} & 0.5 & 0.377 & 0.001539 & 0.022176 & 0.058822 & 174 \\
\hline & & & 0.4 & 0.277 & 0.001539 & 0.022176 & 0.080058 & 126 \\
\hline & & & 0.3 & 0.177 & 0.001539 & 0.022176 & 0.125288 & 79 \\
\hline & & \multirow{3}{*}{0.25} & 0.5 & 0.377 & 0.000616 & 0.00887 & 0.023529 & 71 \\
\hline & & & 0.4 & 0.277 & 0.000616 & 0.00887 & 0.032023 & 52 \\
\hline & & & 0.3 & 0.177 & 0.000616 & 0.00887 & 0.050115 & 33 \\
\hline & \multirow{2}{*}{0.0225} & \multirow{2}{*}{0.2} & 0.4 & 0.277 & 0.001988 & 0.028639 & 0.103391 & 161 \\
\hline & & & 0.3 & 0.177 & 0.001988 & 0.028639 & 0.161804 & 100 \\
\hline
\end{tabular}


Table 2. Distribution of reinforcement according to sub-point b).

\begin{tabular}{|c|c|c|c|c|c|c|c|c|}
\hline \multicolumn{9}{|l|}{ Case b) } \\
\hline orientation & diameter & span & h & d & As & xeff & $\xi$ eff & MRd \\
\hline$[-]$ & {$[\mathrm{m}]$} & {$[\mathrm{m}]$} & [m] & {$[\mathbf{m}]$} & [m2] & [m] & {$[-]$} & {$[\mathrm{kNm}]$} \\
\hline \multirow{3}{*}{ horizontal } & \multirow{3}{*}{0.014} & \multirow{3}{*}{0.1} & 0.5 & 0.493 & 0.000462 & 0.006653 & 0.013495 & 70 \\
\hline & & & 0.4 & 0.393 & 0.000462 & 0.006653 & 0.016928 & 56 \\
\hline & & & 0.3 & 0.293 & 0.000462 & 0.006653 & 0.022706 & 41 \\
\hline \multirow{8}{*}{ vertical } & \multirow{6}{*}{0.014} & \multirow{3}{*}{0.1} & 0.5 & 0.477 & 0.000462 & 0.006653 & 0.013947 & 68 \\
\hline & & & 0.4 & 0.377 & 0.000462 & 0.006653 & 0.017647 & 53 \\
\hline & & & 0.3 & 0.277 & 0.000462 & 0.006653 & 0.024017 & 39 \\
\hline & & \multirow{3}{*}{0.25} & 0.5 & 0.477 & 0.000185 & 0.002661 & 0.005579 & 27 \\
\hline & & & 0.4 & 0.377 & 0.000185 & 0.002661 & 0.007059 & 21 \\
\hline & & & 0.3 & 0.277 & 0.000185 & 0.002661 & 0.009607 & 16 \\
\hline & \multirow{2}{*}{0.0225} & \multirow{2}{*}{0.2} & 0.4 & 0.377 & 0.000596 & 0.008592 & 0.02279 & 69 \\
\hline & & & 0.3 & 0.277 & 0.000596 & 0.008592 & 0.031017 & 50 \\
\hline
\end{tabular}

Table 3. Distribution of reinforcement according to sub-point c).

\begin{tabular}{|c|c|c|c|c|c|c|c|c|}
\hline \multicolumn{9}{|l|}{ Case c) } \\
\hline orientation & diameter & span & h & d & As & xeff & $\xi$ eff & MRd \\
\hline$[-]$ & [m] & {$[\mathrm{m}]$} & [m] & [m] & [m2] & [m] & {$[-]$} & [kNm] \\
\hline \multirow{3}{*}{ horizontal } & \multirow{3}{*}{0.014} & \multirow{3}{*}{0.1} & 0.5 & 0.453 & 0.001539 & 0.022176 & 0.048954 & 210 \\
\hline & & & 0.4 & 0.353 & 0.001539 & 0.022176 & 0.062822 & 162 \\
\hline & & & 0.3 & 0.253 & 0.001539 & 0.022176 & 0.087652 & 115 \\
\hline \multirow{8}{*}{ vertical } & \multirow{6}{*}{0.014} & \multirow{3}{*}{0.1} & 0.5 & 0.437 & 0.001539 & 0.022176 & 0.050746 & 202 \\
\hline & & & 0.4 & 0.337 & 0.001539 & 0.022176 & 0.065804 & 155 \\
\hline & & & 0.3 & 0.237 & 0.001539 & 0.022176 & 0.09357 & 107 \\
\hline & & \multirow{3}{*}{0.25} & 0.5 & 0.437 & 0.000616 & 0.00887 & 0.020298 & 82 \\
\hline & & & 0.4 & 0.337 & 0.000616 & 0.00887 & 0.026322 & 63 \\
\hline & & & 0.3 & 0.237 & 0.000616 & 0.00887 & 0.037428 & 44 \\
\hline & \multirow{2}{*}{0.0225} & \multirow{2}{*}{0.2} & 0.4 & 0.337 & 0.001988 & 0.028639 & 0.084983 & 198 \\
\hline & & & 0.3 & 0.237 & 0.001988 & 0.028639 & 0.120841 & 137 \\
\hline
\end{tabular}

A combination of loads resulting in the greatest effort of the elements selected from the combinations below was accepted as a reliable one:

$1: 1,35 \cdot$ constant $+1,1 \cdot$ ground

$2: 1,0 \cdot$ constant $+1,1 \cdot$ ground

$3: 1,35 \cdot$ constant $+1,2 \cdot$ water $+1,1 \cdot$ ground $\cdot 2$

$4: 1,35 \cdot$ constant $+1,2 \cdot$ water $+0,9 \cdot$ ground $\cdot 2$

$5: 1,35 \cdot 0,9 \cdot$ constant $+1,2 \cdot$ water $+1,1 \cdot$ ground $\cdot 2$

$6: 1,35 \cdot 0,9 \cdot$ constant $+1,2 \cdot$ water $+0,9 \cdot$ ground $\cdot 2$ 
Below, in Figures from 7 to 14, the map of moments in the longitudinal and transverse walls of the tank is shown.

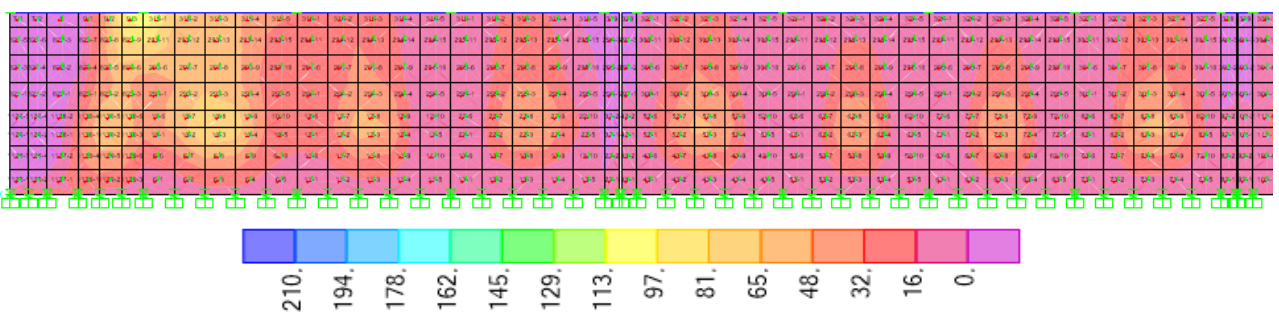

Fig. 7. Longitudinal wall M11 max.

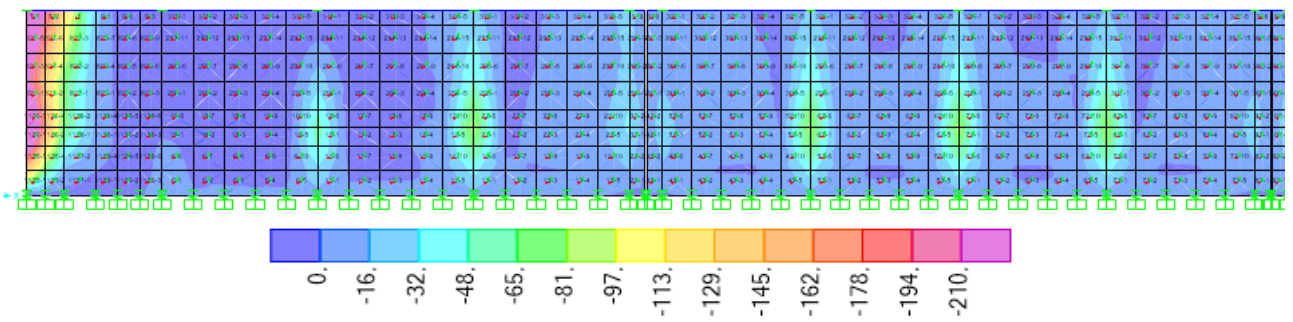

Fig. 8. Longitudinal wall M11 min.

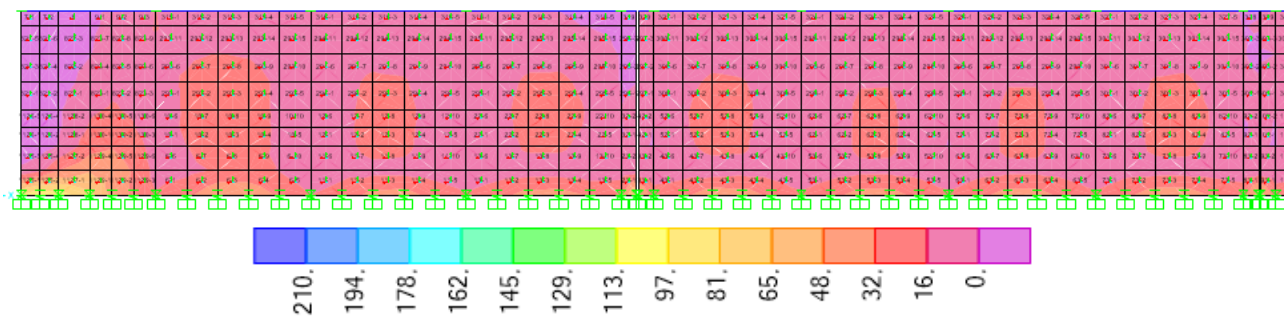

Fig. 9. Longitudinal wall M22 max.

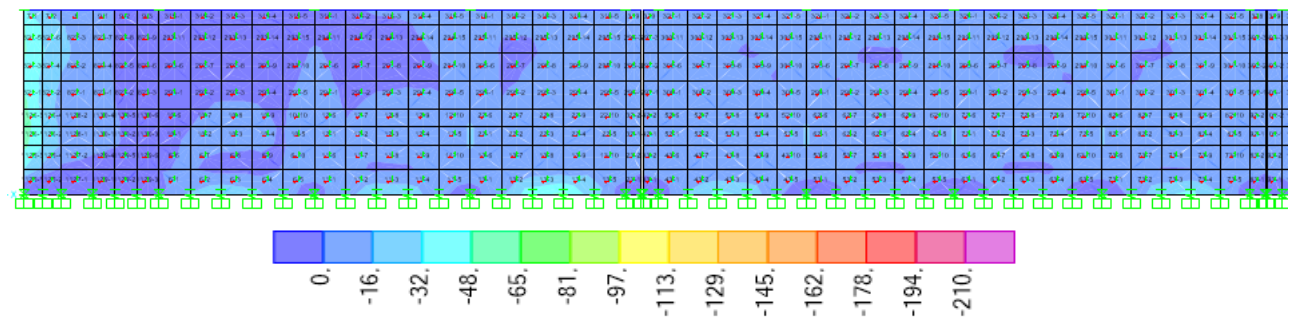

Fig. 10. Longitudinal wall M22 min.
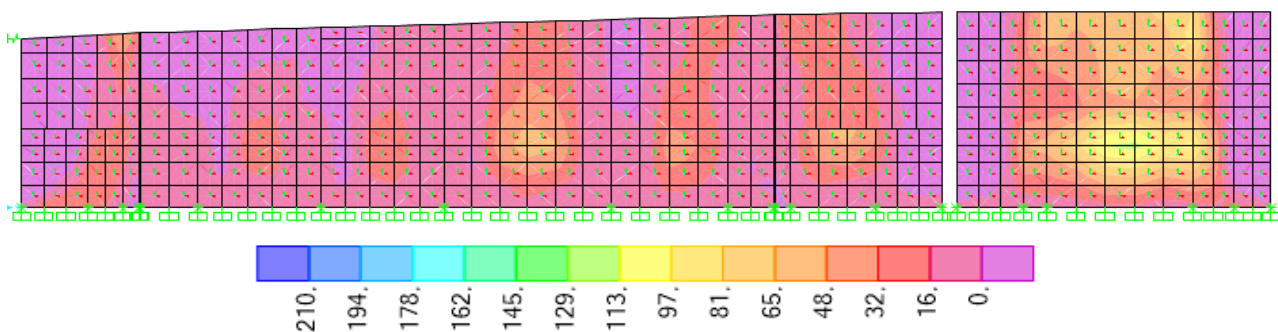

Fig. 11. Transverse wall M11 max. 

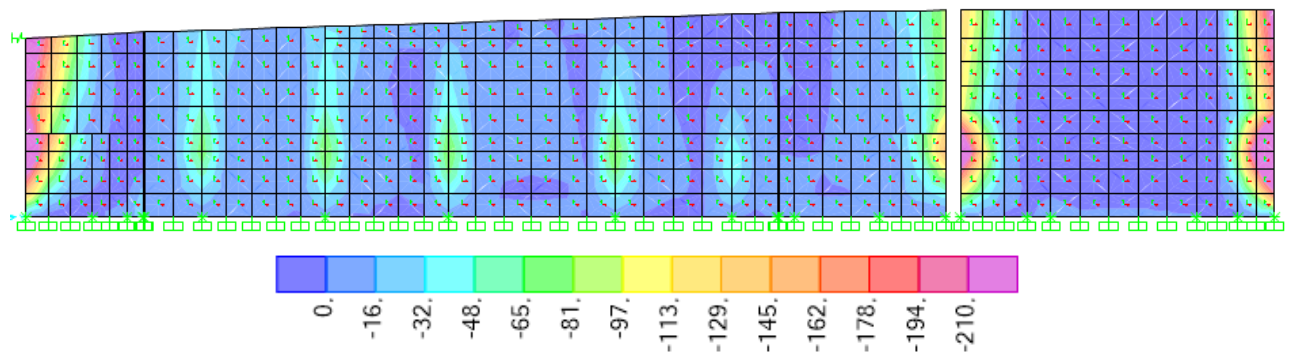

Fig. 12. Transverse wall M11 min.

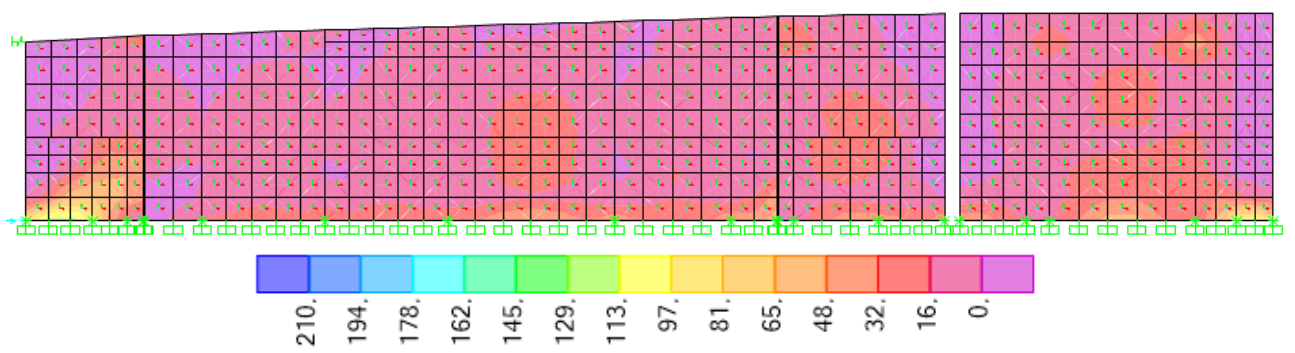

Fig. 13. Transverse wall M22 max.

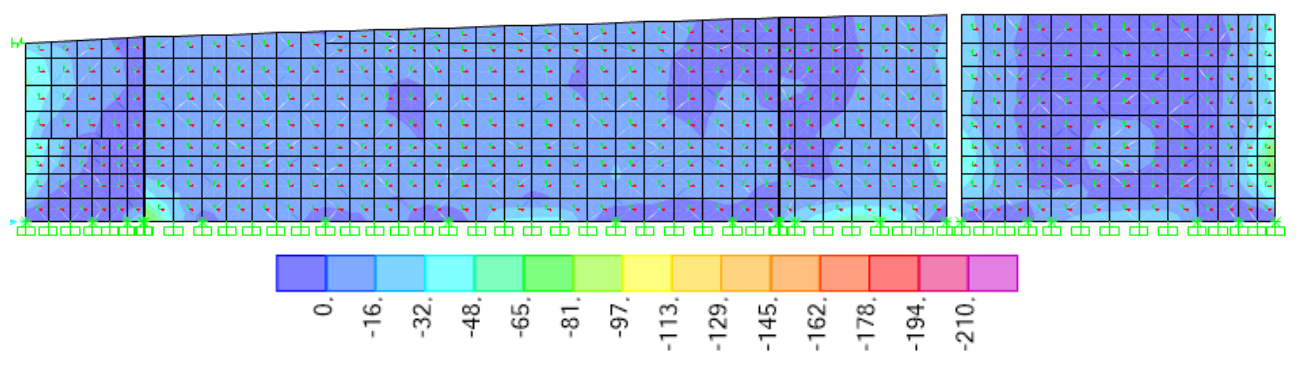

Fig. 14. Transverse wall M22 min.

\subsection{Non-linear model}

As the state of ultimate limit of load capacity in the tank's corner was exceeded, the above assumptions were verified using a non-linear model. Only the case of squeezing the substrate was assumed and the non-linear cooperation of concrete and steel in the corner was taken into account using typical models of material non-linearities built into calculation programs.

The following combination was verified:

$$
1,35 \cdot \text { constant }+1,2 \cdot \text { water }+0,9 \cdot \text { ground } \cdot 2+1,0 \cdot \text { friction }
$$

Fig. 15 shows the use of load-bearing capacity in reinforcing bars of the tank structure in the corner of the gable and longitudinal walls. 


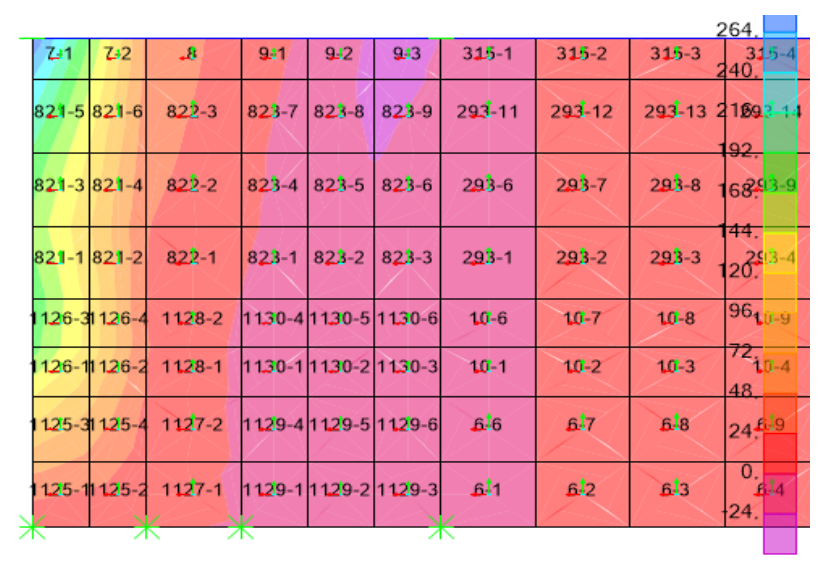

Fig. 15. Use of load-bearing capacity in reinforcing bars in the corner of the tank.

\section{Conclusions and final recommendations}

It is significant that the building user commissioned the expertise not because the facility has been used for 40 years without the required periodic technical inspections and periodic repairs to maintain the proper technical condition of the facility, but because the company recorded financial losses resulting from significant losses of drinking water from the tank. Based on measurements and flow analyses, it was found that as a result of a leak in the tank, water losses amounted to approximately 110,000 to $150,000 \mathrm{~m}^{3}$ during the year, which means significant financial losses for the company.

A detailed scanning of the facility in the form of visual inspection, non-destructive testing and laboratory tests as well as computational analysis enabled a precise diagnosis of the reasons for the poor technical condition of the facility, which formed the basis for preparing repair works in the tank to improve its technical condition and ensure leak tightness.

Due to the lack of space these works were not described in detail. It should only be mentioned that the scratch seal was provided by means of standard sealing systems and renovation of reinforced concrete structures, and the expansion joints sealing was made by means of systemic sealing inserts with simultaneous stitching integrating the expansion joints by means of reinforcing bars. The repair materials had to comply with PZH (National Institute of Public Health in Poland) certificates and remain in conformity with [6].

\section{References}

1. A. Halicka, D. Franczak, Projektowanie zbiorników żelbetowych, zbiorniki na ciecze. (PWN, Warszawa, 2013) [in Polish]

2. PN-EN 1992-3 Eurocode 2 - Design of concrete structures - Part 3: Liquid retaining and containment structures

3. M. Zych, Zarysowanie ścian zbiorników żelbetowych. Teoria i projektowanie. (Politechnika Krakowska, Kraków, 2017) [in Polish]

4. PN-EN 12504-1:2001. Testing concrete in structures. Cored specimens. Taking, examining and testing in compression

5. A.M Neville, Properties of Concrete (Polski Cement, Kraków, 2012)

6. Document : Rozporządzenie Ministra Zdrowia z dnia 7 grudnia 2017 r. w sprawie jakości wody przeznaczonej do spożycia przez ludzi (Dz.U. 2017 poz. 2294) 